\title{
Determinants of Political Content Sharing on Social Media: Impulsiveness, Social Recognition, Risk-taking, and Collective Opinion
}

\author{
İsmail Yelpaze
}

\begin{abstract}
This paper examined what role impulsiveness and perceived social recognition played in the way young adults shared political content on social media. The study also looked into the mediating role of risk-taking and collective opinion in the relationship between these variables. The sample consisted of 554 university students (357 women and 193 men) from six faculties of Kahramanmaraş Sütçü İmam University. Participants were recruited using convenience sampling. The study adopted a predictive correlational design. Data were collected using valid and reliable scales. The results showed that participants with high impulsiveness and perceived social recognition were more likely to share political content on social media. Risk-taking was a partial mediator between perceived social recognition and political content sharing, while it was a full mediator between impulsiveness and political sharing. Collective opinion was a partial mediator between perceived social recognition and political content sharing on social media. The results indicate that young adults with high impulsiveness are more likely to share political content on social media because they can take more risks. Moreover, young adults who care about social recognition are more likely to share political content on social media because they can take more risks and care more about collective opinion.
\end{abstract}

Keywords: Political content sharing, impulsiveness, social recognition, collective opinion, risk-taking, social media.

Öz: İnsanların birçoğu sosyal medyada pekçok konudaki duygu ve düşüncelerini paylaşabilirken, siyasi görüşlerini paylaşamamaktadır. Kullanıcıların bu konuda çekingen davranması ve sorunun arkasında yatan nedenlerin yeterince açığa çıkmamış olması, bu konunun çalışılması gerektiğine işaret etmektedir. Bu çalışma, genç yetişkinlerin sosyal medyadaki siyasi içerikli paylaşımlarında dürtüselliğin ve sosyal tanınma isteğinin rolünü incelemektedir. Bunun yanı sıra bu değişkenler arasındaki ilişkilerde risk almanın ve ortak görüşü önemsemenin aracılık rollerini incelemektedir. Çalışmaya 357'si kadın, 193'ü erkek olmak üzere toplam 554 üniversite öğrencisi katılmıştır. Katılımcılar, Kahramanmaraş Sütçü İmam Üniversitesi'nin 6 farklı fakültesinden kolay ulaşılabilir örnekleme yoluyla gönüllü öğrencilerden seçilmiştir. Araştırma, nicel desenlerden yordayıcı ilişkisel desen ile yürütülmüştür. Veriler; Ortak Görüş Ölçeği, Risk Alma Ölçeği, Sosyal Tanınma Ölçeği, Dürtüsellik Ölçeği ve Politik Paylaşım Ölçeği ile toplanmıştır. Araştırmanın bulgularına göre; dürtüsel olan ve sosyal tanınmayı önemseyen kişiler, sosyal medyada daha fazla siyasi içerikli paylaşım yapmaktadırlar. Sosyal tanınma ile sosyal medyada siyasi içerikli paylaşım yapma arasındaki ilişkide risk alma ve ortak görüşe önem vermenin kısmi aracılık rolü bulunmaktadır. Ayrıca dürtüsellik ve siyasi içerikli paylaşım arasındaki ilişkide, risk almak tam aracılık rolüne sahiptir. Sonuç olarak; dürtüselliği yüksek olan genç yetişkinler, risk alabildiklerinden , sosyal tanınmayı önemseyenler ise risk alabildiklerinden ve ortak fikirlere önem verdiklerinden sosyal medyada siyasi içerikli paylaşımlar yapmaktadırlar.

Anahtar Kelimeler: Siyasi içerikli paylaşım, dürtüsellik, sosyal tanınma, ortak görüş, risk alma, sosyal medya.

Assist. Prof.. Üyesi, Kahramanmaraş Sütçü İmam University, ismailyelpaze@gmail.com

(iD)

https://orcid.org/0000-0003-4428-0502 


\section{Introduction: Political Content Sharing}

Most people today have smart devices and social media accounts through which they establish and maintain social relationships. Almost one out of two people (42\%, 3.196 billion) was a social media user in 2018 (Chaffey, 2019). There are many reasons why social media is so popular. One of the reasons is that more than half of the world's population has technological devices and Internet access. Almost seven out of ten people (68\%) use mobile phones, and one out of two (53\%) have Internet access (Chaffey, 2019). Another reason is that social media is an interactive environment that is fun to be in and to communicate and learn new things. People share their feelings and opinions on social media to feel involved and let others know them (Ceyhan \& Yelpaze, 2017).

Many users avoid sharing their political opinions on social media because they are afraid that they may get into trouble (Stutzman, 2006). They have their own reasons to worry about sharing content on social media because they may face legal sanctions (Grimmelmann, 2009), get attacked by hackers, and get their privacy invaded (Jernigan \& Mistree, 2009), or become targets of cyberbullying (Palfrey, 2008). Users with high anonymity preference tend to read the privacy policies of every website they visit and every app they use, and therefore, they are likely to be more aware of possible risks and share less content on social media (Stutzman, Capra \& Thompson, 2011).

Social media users share different content. While leaders can readily share their opinions on social media, laypeople do it to a lesser degree (Ceyhan \& Yelpaze, 2017) because the latter has to take some other factors into account. Though social media platforms allow users to disseminate their political ideas or agendas (Kapoor \& Dwivedi, 2015), doing that often comes at a price. For example, a man in Thailand was arrested for sharing a doctored photo of the King with friends on Facebook (Bhutia, 2015). A man in Russia was sentenced to two years in prison for sharing a post of a Ukrainian nationalist. The list goes on. Despite the risks, at least one-third of social media users discuss, comment, or post political content on social media (Duggan \& Smith, 2016). There is no easy answer as to how come people knowing the risks, still take them. Many users do not share political content on social media, but some still do it, despite adverse consequences. The reason behind this is yet to be ascertained. Therefore, this paper investigated the impact of social recognition, Impulsiveness, collective opinion, and risk-taking on political content sharing on social media. 


\section{Perceived Social Recognition}

Knowledge sharing is defined as the interchange of knowledge between units (individuals or institutions). People tend to share knowledge because it comes with reciprocal benefits and reputation/social recognition (hereinafter, social recognition) (Davenport \& Prusak, 1997). Two antecedents of knowledge sharing are anticipated extrinsic rewards and anticipated reciprocal relationships (Bock \& Kim, 2002). Social recognition provides social reward. In this study, social recognition was defined as "the degree to which a social media user believes that political content sharing can enhance personal recognition." For some people, social recognition is a reward that shapes their behavior. For example, they need to reach out to a broader audience to increase social recognition. Social media is one of the most effective of those platforms. People who want to be recognized may think that sharing their opinions on social media will make them socially more recognized. Research shows that people share content on social media to be recognized and perceived as experts (Dwivedi, Rana, Jeyaraj, Clement \& Williams, 2017; Park, Gu, Leung \& Konana, 2014). Political content has a large share in today's digital world. Sharing political opinions may bring with it popularity among like-minded people.

H.1: University students seeking social recognition are more likely to share political content on social media platforms.

\section{Impulsiveness}

Impulsiveness is defined as one' inclination to initiate action without thinking about its consequences (Park, Keil, Bock \& Kim, 2016). Impulsiveness has three independent structures: (1) acting without thinking, (2) impatience, and (3) a tendency to engage in risky behavior (Romer, 2010). Impulsive people are more emotional about political content sharing (Hossain, Dwivedi, Chan, Standing \& Olanrewaju, 2018). A Bangladeshi man was sentenced to six months in jail for 'copying and pasting' a comment on Facebook wishing for the prime minister's death (Orr, 2012). This suggests that impulsive people are more likely to act on a whim and share political content without considering its consequences.

H.2. University students with high impulsiveness are more likely to share political content on social media platform. 


\section{Collective Opinion}

According to the theory of planned behavior (TPB), social norms positively affect behavior (Ajzen, 1991). The concept of social norm is defined as the degree to which one perceives others' approval of one's behavior (Hsu \& Lin, 2008). Approval shapes behavior (Lim \& Ting, 2014). People tend to trust information upheld by the majority (Metzger, 2010). For example, product endorsements affect purchasing behavior (Moe \& Schweidel, 2012), and social media users tend to like posts with many likes (Sakamato, 2009). This is defined as "collective opinion" (Moe \& Schweidel, 2012). The concepts of social norm and collective opinion are very similar. People's preferences are significantly affected by collective opinions, such as envy or cohesion (Lahno \& Serra-Garcia, 2015). This study posits that collective opinion plays a significant role in political content sharing and that collective opinion is a mediator between social recognition and political sharing.

People post on social media to increase social recognition, but they also make sure that others approve of their posts because otherwise, they find themselves in controversies or lose friends. Media experts suggest that people avoid sharing controversial content on social media because that type of post may cost them their friends (Antczak 2016; Duggan \& Smith 2016). Therefore, people who share their political opinions on social media to increase social recognition should also take collective opinions into account.

H.3. Collective opinion plays a mediating role in the relationship between social recognition and political content sharing on social media among university students.

\section{Risk-taking}

Risk-taking refers to decisions or actions that are uncertain or have at least one adverse consequence (van Duijvenvoorde, Blankenstein, Crone \& Figner, 2016). Although risk-taking behaviors extend into adulthood (Grunbaum et al., 2004), they are more common in adolescence (Kıran-Esen, 2003; Willoughby, Good, Adachi, Hamza \& Tavernier, 2013). Adolescence and young adulthood are challenging due to numerous developmental tasks, such as identity formation, career choice, marriage, academic performance, etc. Adolescents and young adults experience tension and stress, resulting in risk-taking behaviors (Gençtanırım, 2014). Adulthoods feel like everybody is watching and admiring them and think that no harm will come to them because of their actions (Lapsley, Milstead, Quintana, Flannery \& Buss, 1986). 
Research also shows that people with social media profiles are more likely to take risks than those without social media profiles (Fogel \& Nehmad, 2009).

Risk-taking behaviors are not always harmful or dangerous, but they strike a balance between positive and adverse outcomes (Moore \& Gullone, 1996). Risk-taking can help one gain independence, oppose norms, develop an identity, mature, and be accepted by peers (Peterson et al., 2003). It also provides one with the opportunity to build self-confidence in one's identity formation process (Akça, 2017). If a risky behavior has more advantages than disadvantages, it is considered a coherent behavior (Byrnes, Miller \& Schafer, 1999). Risk-taking behavior can play an essential role in social recognition. One may need to conduct different behaviors to attract others' attention, thus increasing social recognition. Therefore, people who care about social recognition may be more likely to take risks in sharing political content on social mediafactor for people who care about social recognition to be able to take some risks while making political sharing.

H.4. Risk-taking plays a mediating role in the relationship between social recognition and political content sharing on social media among university students.

Impulsiveness is another factor affecting political content sharing on social media. It is defined as focusing on short-term gains rather than long-term gains regardless of the size of the reward (Ainslea, 1975). Impulsive people underestimate threats and engage in risky behavior for excitement and pleasure (Hollander \& Evers, 2001). Therefore, we can argue that risk-taking plays a crucial role in the relationship between impulsiveness and political content sharing on social media.

H.5. Risk-taking plays a mediating role in the relationship between social recognition and political content sharing on social media among university students.

Figure 1 shows the holistic model of hypotheses.

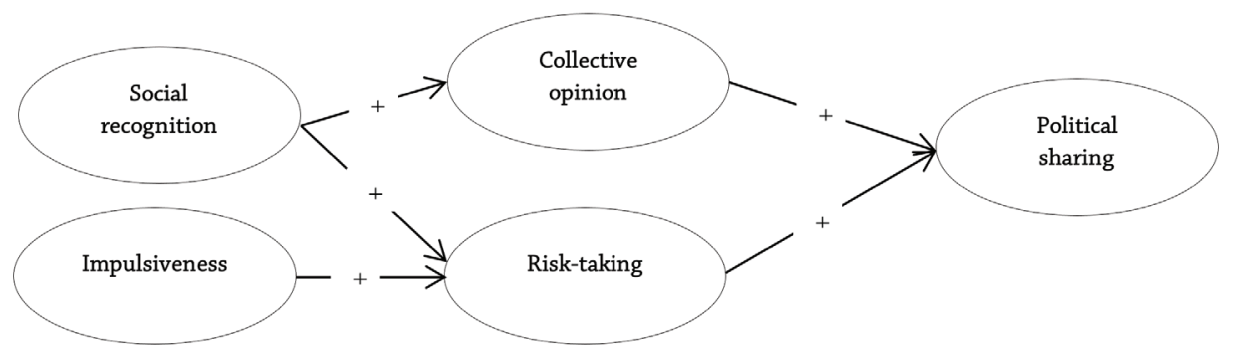

Figure 1. Hypothetical structural model 


\section{Problem statement}

Many social media users avoid sharing their political opinions because they may face charges. There is no published research investigating the factors affecting political content sharing on social media. We think that determining those factors will contribute to the literature and provide a better understanding of the phenomenon. Therefore, this paper looked into the factors affecting young adults' tendency to share political content on social media.

\section{Importance of the study}

There is a growing body of research on social media because it is becoming increasingly popular amongst all age groups. Most research focuses on the number of users, screen time, addiction, and general content sharing (Ma \& Chan, 2014; Osatuyi, 2013). However, there is little research on political sharing on social media (Hossain et al., 2018). To our knowledge, no studies have investigated political content sharing tendencies of Turkish people, who share their opinions on various topics but avoid sharing their political opinions on social media platforms (Ceyhan \& Yelpaze, 2017). Therefore, there is a gap in the literature regarding the factors encouraging or discouraging Turkish people from sharing political content on social media platforms. We think that this study will pave the way for further research. Although our results cannot be generalized to the whole population, they shed slight on variables that may affect the general trend. Therefore, researchers can use our data to provide a critique of behavioral theories. One of those theories is the TPB, according to which attitudes and intentions determine behaviors (Ajzen, 1991). For example, someone with negative attitudes towards and with no intention of sharing content on social media is less likely to do so. This study hypothesized that "people who find it risky (negative attitude) to share political content on social media and think that it will contribute to their social recognition (positive attitude) are more likely to share political content on social media (positive behavior). The theory of planned behavior was discussed in the context of the results..

The rationale was that university students transition from adolescence to early adulthood, a period where they form their own identities and adopt political opinions. University students are expected to do research, ask questions, criticize long-held assumptions and convictions, and express their thoughts. However, it is not the case when it comes to sharing political content on social media. We think that our results will help perceive barriers to political content sharing and make 
suggestions to let young generations express their thoughts and share them on social media platforms freely.

\section{Method}

The aim of this study is to determine whether perceived social recognition, impulsivity, collective opinion and risk taking behavior are predictors of political content sharing in social media. For this purpose, predictive correlational research design of quantitative research methods was used. This design helps us to predict future conditions or behaviors in one variable from what we presently know of another variable (Cresswell, 2016).

\section{Participants}

Participants were selected from volunteer students from 6 different faculties of the university via convenience sampling. The measurement tools were applied to the students face to face in the classroom. Following the data collection period, some data were not included in the survey because they were not filled according to the guidelines, or more than $1 \%$ of the scales are left blank. As a conclusion 554 students from Kahramanmaraş Sütçü İmam University at an Anotolian city participated in the research. Collectivistic cultural features are dominant in the city where the university is located. Students of the university come mostly from the surrounding cities or further east. Therefore, it can be inferred that the participant students also have collectivistic cultural characteristics and are conservative. Culture is a determining factor in people's behavior. In this respect, this explanation is included in order to make the research results more understandable for the reader. Table 1 shows participants' descriptive statistics. 
insan \& toplum

Table 1.

Descriptive statistics of participants

\begin{tabular}{|c|c|c|c|c|}
\hline \multicolumn{3}{|l|}{ Variables } & $\mathrm{f}$ & $\%$ \\
\hline \multirow{2}{*}{ Gender } & \multicolumn{2}{|l|}{ Female } & 358 & 64.6 \\
\hline & \multicolumn{2}{|l|}{ Male } & 193 & 34.8 \\
\hline \multirow{4}{*}{ Classroom level } & \multicolumn{2}{|l|}{ Freshman } & 229 & 41.3 \\
\hline & \multicolumn{2}{|l|}{ Sophomore } & 96 & 17.3 \\
\hline & \multicolumn{2}{|l|}{ Junior } & 202 & 36.5 \\
\hline & \multicolumn{2}{|l|}{ Senior } & 18 & 3.2 \\
\hline \multirow{6}{*}{ GPA } & \multicolumn{2}{|l|}{$0-1.49$} & 17 & 3.1 \\
\hline & \multicolumn{2}{|l|}{$1.50-1.99$} & 67 & 12.1 \\
\hline & \multicolumn{2}{|l|}{$2.00-2.49$} & 140 & 25.3 \\
\hline & \multicolumn{2}{|l|}{$2.50-2.99$} & 203 & 36.6 \\
\hline & \multicolumn{2}{|l|}{ 3.00-3.49 } & 99 & 17.9 \\
\hline & \multicolumn{2}{|l|}{$3.50-4.00$} & 25 & 4.5 \\
\hline \multirow{6}{*}{ Faculty } & \multicolumn{2}{|c|}{ Faculty of Engineering } & 62 & 11.1 \\
\hline & \multicolumn{2}{|c|}{ Faculty of Education } & 175 & 31.4 \\
\hline & \multicolumn{2}{|c|}{ Faculty of Fine Arts } & 10 & 1.8 \\
\hline & \multicolumn{2}{|c|}{$\begin{array}{l}\text { Faculty of Economics and } \\
\text { Administrative Sciences }\end{array}$} & 95 & 17.1 \\
\hline & \multicolumn{2}{|c|}{ Faculty of Science and Letters } & 150 & 26.9 \\
\hline & \multicolumn{2}{|c|}{ Faculty of Theology } & 65 & 11.7 \\
\hline \multirow{8}{*}{$\begin{array}{l}\text { Sharing content on } \\
\text { social media }\end{array}$} & \multicolumn{2}{|c|}{ Funny } & 236 & 42.6 \\
\hline & \multicolumn{2}{|l|}{ Social event } & 161 & 29.1 \\
\hline & \multicolumn{2}{|l|}{ Political event } & 56 & 10.1 \\
\hline & \multicolumn{2}{|l|}{ Private life } & 330 & 59.6 \\
\hline & \multicolumn{2}{|l|}{ Occupational } & 65 & 11.7 \\
\hline & \multicolumn{2}{|l|}{ Religious } & 92 & 16.6 \\
\hline & \multicolumn{2}{|l|}{ Romantic } & 120 & 21.7 \\
\hline & Min. & Max. & \multicolumn{2}{|c|}{ Average } \\
\hline Age range & 18 & 36 & & \\
\hline $\begin{array}{l}\text { Time (hour) spent on } \\
\text { social media (weekly) }\end{array}$ & 0.5 & 119 & & \\
\hline
\end{tabular}


As seen in Table 1, in terms of gender of participants, 358 (64.6\%) were female, 193 (34.8) were male and 3 of them were missing value. The age range was between 18 and 36, age mean was 20.95. In terms of classroom level, 229 (41.3\%) were freshman, 96 (17.3\%) were sophomore, 202 (36.5) were junior and 18 (3.2\%) were senior. Regarding the participants' profile in terms of faculty, 62 (11.1\%) were at engineering, 175 (31.4\%) were at education, 10 (1.8\%) were at fine and arts, 95 (17.1\%) were at economics and administrative sciences, 150 (26.9\%) were at science and letters and 65 (11.7\%) were at theology. Most of them (61.9) have 2.00-2.99 GPA.

\section{Assessment Tools}

\section{Political Sharing Scale}

Some items of political sharing assessment tool (Ex: The advice I receive from other members using the social media has increased my knowledge about my political view) were adapted from Ma and Chan (2018), several items (Ex: I use social media effectively to pass on my political opinion to others) were added by the researcher. This assessment tool measures the sharing political content of individuals on the social media. Total score is taken from the measurement tool and increase of score shows the individuals have more intense to share political content on social media. The validity and reliability study was conducted with 127 university students, 89 females and 38 males. Five point likert type assessment tool consists of six items and the factor loadings of the items range from .53 to .83. The scale explains $56 \%$ of variance and it has reliability coefficient of .84. Reliability coefficient in current study is .87. Confirmatory factor analysis was performed in the current study and it was seen that the goodness of fit indices was sufficient $\left(\chi^{2} / \mathrm{df}=2.11, \mathrm{RMSEA}=.04\right.$, $\mathrm{CFI}=.99$, IFI=.99 and $\mathrm{NFI}=.99)$.

\section{Impulsiveness Scale}

Some items of impulsiveness scale (Ex: I often behave without thinking of the consequences) were adapted from Park, Keil, Bock, and Kim (2016) and some of them were written by researcher. This assessment tool measures how people behave impulsive. Total score is taken from the measurement tool and increase of score shows the individuals behave more impulsive. The validity and reliability study was conducted with 127 university students, 89 females and 38 males. Five point likert type assessment tool consists of seven items and the factor loadings of the items range from .44 to .77. The scale explains $33 \%$ of variance 
and it has reliability coefficient of .65. Reliability coefficient in current study is .68. Confirmatory factor analysis was performed in the current study and it was seen that the goodness of fit indices was sufficient $\left(\chi^{2} / \mathrm{df}=2.28, \mathrm{RMSEA}=.04\right.$, $\mathrm{CFI}=.98, \mathrm{IFI}=.98$ and $\mathrm{NFI}=.97)$.

\section{Social Recognition Scale}

Social recognition Scale (Ex: Sharing on social media improves my image) was adapted from Shiau and Chau (2015). Total score is taken from the measurement tool and increase of score shows the individuals perceive their social recognition more effective and social recognition. The validity and reliability study was conducted with 127 university students, 89 females and 38 males. Five point likert type assessment tool consists of five items and the factor loadings of the items range from .67 to .91. The scale explains $67 \%$ of variance and it has reliability coefficient of .86. Cronbach alpha value in current study is .86, too. Confirmatory factor analysis was performed in the current study and it was seen that the goodness of fit indices was sufficient $\left(\chi^{2} / \mathrm{df}=2.85, \mathrm{RMSEA}=.05, \mathrm{CFI}=.99, \mathrm{IFI}=.99\right.$ and $\left.\mathrm{NFI}=.99\right)$.

\section{Risk Taking Scale}

Items of the scale (Ex: Even if it gets me into trouble, I make political posts and comments on social media) were composed by researcher. Total score is taken from the measurement tool and increase of score shows the individuals can behave riskier. The validity and reliability study was conducted with 127 university students, 89 females and 38 males. Five point likert type assessment tool consists of seven items and the factor loadings of the items range from .57 to .84 . The scale explains $57 \%$ of variance and it has reliability coefficient of .87. Reliability coefficient in current study is .87. Confirmatory factor analysis was performed in the current study and it was seen that the goodness of fit indices was sufficient $\left(\chi^{2} / \mathrm{df}=2.70, \mathrm{RMSEA}=.05\right.$, $\mathrm{CFI}=.98, \mathrm{IFI}=.98$ and $\mathrm{NFI}=.97)$.

\section{Collective Opinion Scale}

The scale (Ex: High numbers of likes/shares/followers are important to me) was adapted from Sakamoto and Nickerson (2009). Total score is taken from the measurement tool and increase of score shows that people adopt ideas and behaviors more easily if they are adopted by large groups. The validity and reliability study was conducted with 127 university students, 89 females and 38 males. The assessment tool consists of four items and the factor loadings of the items range from .74 to .86. The scale explains $66 \%$ of variance and it has reliability coefficient of .82. Reliability coefficient in current study is .81 . Confirmatory factor analysis was performed in the current 
study and it was seen that the goodness of fit indices was sufficient $\left(\chi^{2} / \mathrm{df}=2.84\right.$, RMSEA=.05, CFI=.99, IFI=.99 and NFI=.99).

\section{Data Collection and Analysis}

We created a booklet of an informed consent form and the scales. We conducted a pilot test to check how long the data collection lasted and whether the scales were reliable. The sample consisted of 554 voluntary students from the Kahramanmaraş Sütçü İmam University. We obtained permission from lecturers at different faculties to recruit as many students as possible.

We made the data compatible with the analysis to address the issue of lost data. When the ratio of lost data is minimal, it is recommended that simple assignment-based methods be used, such as assigning series means, near point median assignment, linear valuation, etc. (Osborne, 2013). We employed the series mean assignment method to assign approximate values to the lost data. Before analysis, we examined the initial conditions of the structural equation model (SEM) and ensured that the kurtosis-skewness ranged from -3 to +3 (Tabachnick \& Fidell, 2001). We performed the structural equation modeling to investigate the role of risk-taking and collective opinion between social recognition and political sharing on social media and risk-taking between impulsive behavior and political sharing on social media. The goodness-of-fit indices of $\chi 2 / \mathrm{df}$, RMSEA, CFI, IFI, NFI were used. The accepted value for $\chi 2 / \mathrm{df}$ is $<5$ (Bollen, 1989). The accepted value for CFI, IFI, and NFI are > .90 (Bentler \& Bonett, 1980; Hooper, Coughlan \& Mullen, 2008). The accepted value for RMSEA is < .80 (Brown \& Cudeck, 1993; Schreiber, Nora, Stage, Barlow \& King, 2006). To decide the best model, we applied AIC and ECVI values and chi-square differentiation tests on the SEMs and accepted the model with the smallest AIC and ECVI values (Kline, 2015). 


\section{Results}

\section{Table 2.}

Relationship among variables and descriptive statistics of variables

\begin{tabular}{|l|c|c|c|c|c|}
\hline & 1 & 2 & 3 & 4 & 5 \\
\hline 1. Political sharing & - & & & & \\
\hline 2. Impulsiveness & $.11^{*}$ & - & & & \\
\hline 3. Social recognition & $.34^{* *}$ & $.09^{*}$ & - & & \\
\hline 4. Risk taking & $.54^{* *}$ & $.16^{* *}$ & $.12^{* *}$ & - & \\
\hline 5. Collective opinion & $.35^{* *}$ & .05 & $.53^{* *}$ & $.10^{*}$ & - \\
\hline Mean & 10.77 & 21.92 & 9.64 & 14.87 & 8.32 \\
\hline SD & 5.25 & 4.64 & 4.65 & 7.11 & 3.88 \\
\hline Skewness & 1.17 & .16 & 1.03 & .76 & .68 \\
\hline Kurtosis & .98 & .04 & .44 & -.32 & -.35 \\
\hline
\end{tabular}

As it can be seen in Table 2, political sharing was positively correlated with impulsiveness (.11), social recognition (.34), risk-taking (.54), and collective opinion (.35). Social recognition was positively correlated with risk-taking (.12) and collective opinion (.53). Lastly, impulsiveness was positively correlated with risk-taking (.16). These results suggested that these variables could be used together for structural equation modeling.

The structural equation modeling was carried out in two stages. First, the measurement model and then the hypothetical structural model was tested. In the measurement model, confirmatory factor analysis was performed on all variables. The latent variable is associated with observation/indicator variables that compose them, and the relationships of all variables of the measurement model are discussed. It is recommended that the researcher take into account all error variances in the measurement model and observe all networks of relationships (Kline, 2015).

The structural model had five latent variables and ten observed variables. Since the measurement tools were one-dimensional, we used the parceling method to create two observed variables for each latent variable. The parceling method results in virtual factors, helping us increase reliability and have a normal distribution by reducing the number of observed variables (Nasser-Abu Alhija \& Wisenbaker, 2006). Compared to using each item of the respective scale as an indicator, parcels have more robust psychometric properties, such as higher reliability, more precise identification of the latent construct, and fewer parameter estimates (Kline, 2015). We 
took factor loadings into account to create two parcels for each measurement tool and included them in the measurement model and the structural model analysis. Figure 2 shows the results of the confirmatory factor analysis.

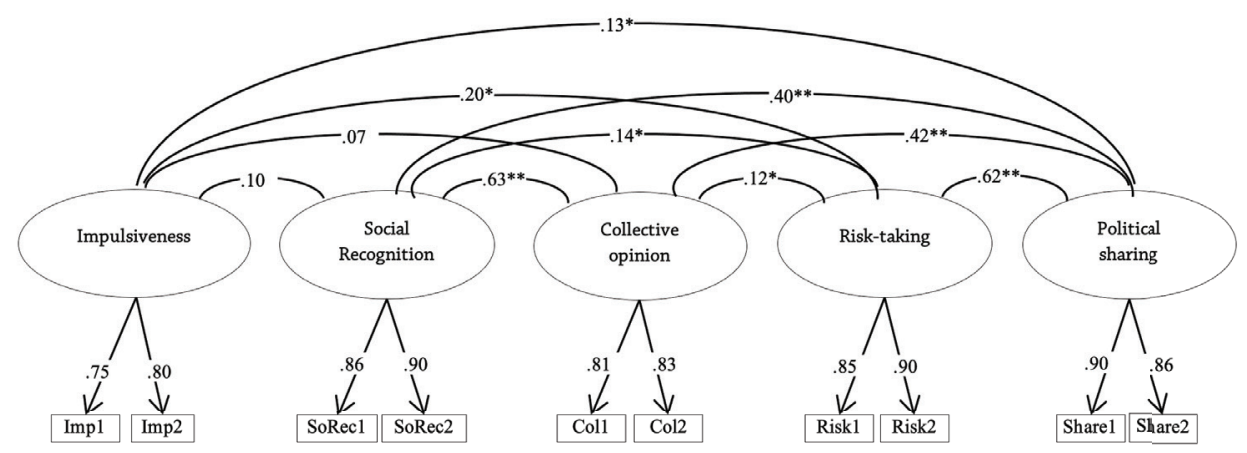

Figure 2. Measurement model

As shown in Figure 2, the standardized regression coefficients in the measurement model ranged from .75 to .90 ( $\mathrm{p} \leq .001$ ) (Figure 2). The goodness-of-fit-indices were acceptable $(\chi 2(25, \mathrm{~N}=554)=41.635, \mathrm{p} \leq .001 ; \chi 2 / \mathrm{df}=1.665 ; \mathrm{CFI}=.99 ; \mathrm{IFI}=.99$; $\mathrm{NFI}=.98 ; \mathrm{RMSEA}=.03 ; \mathrm{CI}=0.14-0.53 ; \mathrm{AIC}=121.635 ; \mathrm{ECVI}=0.220$.), confirming the measurement model. Each indicator loaded well on their respective latent constructs. The measurement model met the necessary conditions for structural modelling.

We used the structural equation model to determine what role risk-taking played in the relationship between impulsiveness and political content sharing on social media and what role collective opinion and risk-taking played in the relationship between social recognition and political content sharing on social media. We used more than one model to determine the most accurate model. Table 3 shows the results.. 


\section{Table 3.}

Structural equation modeling and goodness of fit indices for all four models

\begin{tabular}{|c|c|c|c|c|}
\hline Model & Path (from-to) & Std B & S.E & $\mathrm{p}$ \\
\hline \multirow{3}{*}{ Model 1} & Social recognition - political sharing & .38 & .06 & .001 \\
\hline & Impulsive - political sharing & .10 & .07 & .03 \\
\hline & \multicolumn{4}{|c|}{$\chi^{2} / \mathrm{df}=1.68, \mathrm{RMSEA}=.03, \mathrm{CFI}=.99, \mathrm{IFI}=.99$ and $\mathrm{NFI}=.99$} \\
\hline \multirow{8}{*}{ Model 2} & Social recognition - Collective opinion & .63 & .03 & .001 \\
\hline & Social recognition - risk taking & .13 & .06 & .008 \\
\hline & Impulsive - risk taking & .19 & .10 & .003 \\
\hline & Risk taking - political interest & .58 & .03 & .001 \\
\hline & Collective opinion - political sharing & .25 & .07 & .001 \\
\hline & Social recognition - political sharing & .16 & .05 & .003 \\
\hline & Impulsive - political sharing & -.02 & .05 & .66 \\
\hline & \multicolumn{4}{|c|}{$\chi^{2} / \mathrm{df}=1.64, \mathrm{RMSEA}=.03, \mathrm{CFI}=.99, \mathrm{IFI}=.99$ and NFI $=.98$} \\
\hline \multirow{7}{*}{ Model 3} & Social recognition - Collective opinion & .63 & .03 & .001 \\
\hline & Social recognition - risk taking & .13 & .06 & .008 \\
\hline & Impulsive - risk taking & .19 & .10 & .003 \\
\hline & Risk taking - political sharing & .58 & .03 & .001 \\
\hline & Collective opinion - political sharing & .25 & .07 & .001 \\
\hline & Social recognition - political sharing & .16 & .05 & .003 \\
\hline & \multicolumn{4}{|c|}{$\begin{array}{l}\chi^{2} / \mathrm{df}=1.59, \mathrm{RMSEA}=.03, \mathrm{CFI}=.99, \mathrm{IFI}=.99 \text { and } \mathrm{NFI}=.98 ; \mathrm{AIC}=118.17 \text {, } \\
\mathrm{ECVI}=.21\end{array}$} \\
\hline \multirow{6}{*}{ Model 4} & Social recognition - Collective opinion & 65 & .04 & .001 \\
\hline & Social recognition - risk taking & 14 & .06 & .005 \\
\hline & Impulsive - risk taking & .19 & .10 & .003 \\
\hline & Risk taking - political sharing & .59 & .03 & .001 \\
\hline & Collective opinion - political sharing & .37 & .06 & .001 \\
\hline & \multicolumn{4}{|c|}{$\begin{array}{l}\chi^{2} / \mathrm{df}=1.82, \mathrm{RMSEA}=.04, \mathrm{CFI}=.99, \mathrm{IFI}=.99 \text { and } \mathrm{NFI}=.98 ; \mathrm{AIC}=124.55 \text {, } \\
\mathrm{ECVI}=.22\end{array}$} \\
\hline
\end{tabular}

First, the effect of social recognition and impulsiveness on political content sharing was examined (Model 1). The goodness fit indices of the partial mediating model were $\chi 2 / \mathrm{df}=1.68$, RMSEA=.03, $C F I=.99$, IFI=.99, and NFI=.99. In Model 1, social recognition $(\beta=.38, \mathrm{p} \leq .001)$ and impulsiveness significantly predicted political sharing $(\beta=.10, \mathrm{p} \leq .05)$. 
Model 2 tested the role of social recognition in political sharing via risk-taking and collective opinion and the role of impulsiveness in political sharing via risk-taking. The model had five latent variables and eight observed variables. We first tested the partial mediating role of risk-taking between collective opinion and social recognition and political sharing and then the partial mediating role of risk-taking between impulsiveness and political sharing. The goodness fit indices were $\chi^{2}$ / $\mathrm{df}=1.64, \mathrm{RMSEA}=.03, \mathrm{CFI}=.99, \mathrm{IFI}=.99$, and $\mathrm{NFI}=.98$. The independent variables significantly predicted the mediator and dependent variables, but impulsiveness did not significantly predict political sharing $(\beta=-.02, \mathrm{p}>.05)$. Therefore, we removed the direct path between impulsiveness and political sharing from the model.

Model 3 tested the partial mediating role of risk-taking and collective opinion between social recognition and political sharing and the full role of risk-taking between impulsiveness and political sharing. The goodness fit indices were $\chi 2 / \mathrm{df}=1.59$, RMSEA=.03, $\mathrm{CFI}=.99$, IFI=.99, $\mathrm{NFI}=.98, \mathrm{AIC}=118.17$, and $\mathrm{ECVI}=.21$.

Model 4 tested the full mediating model. The goodness-of-fit indices were $\chi^{2 /}$ $\mathrm{df}=1.82$, RMSEA=.04, $\mathrm{CFI}=.99$, IFI=.99, NFI=.98, $\mathrm{AIC}=124.55$, and $\mathrm{ECVI}=.22$. We analyzed the partial (Model 3) and full mediating model (Model 4) and decided that the partial mediating model was the best one (Figure 5). Therefore, the AIC and ECVI values of the partial model were smaller, and the chi-square differentiation was significant $(\Delta \chi 2=8.387>3.841, \mathrm{df}=1, \mathrm{p} \leq 0.01)$.

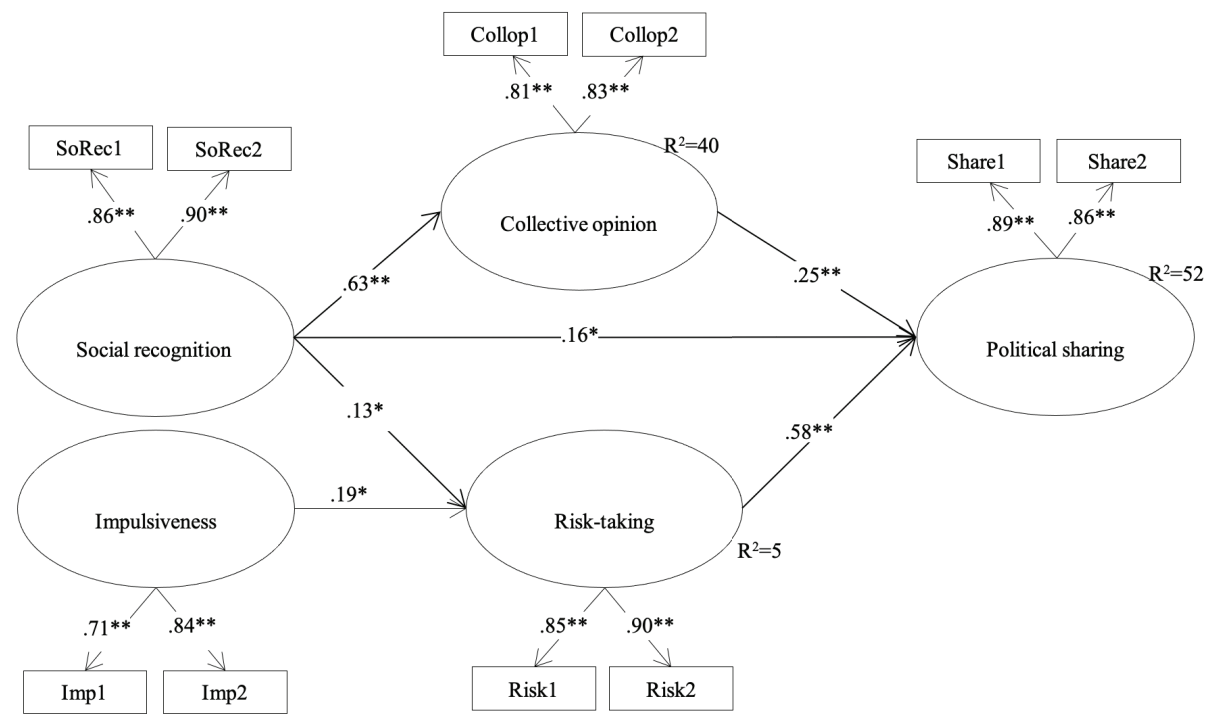

Figure 3. Partially mediated model 


\section{Discussion and Conclusion}

Many social media users avoid sharing their political opinions because they are afraid of getting in trouble. However, some users still do it, despite adverse consequences. The reason behind this is yet to be ascertained. Therefore, this paper investigated whether perceived social recognition and impulsiveness predicted political content sharing on social media. The study also looked into the mediating effect of collective opinion and risk-taking in the relationship between those variables. People who care about social recognition are more likely to share political content on social media. Research shows that social recognition is a strong motivation behind political sharing on social media platforms (Park, Gu, Leung \& Konana, 2014). Social media is an easy and cost-effective way of reaching the target audience. Forty-five percent of the world's population were social media users in 2018 (Chaffey, 2019), which was even higher in Europe (55\%) and America (66\%) (Global Digital Overview, 2019). It is no surprise that users share political content on social media platforms because it attracts others' attention. However, not everybody who wants to be socially recognized shares their political opinions on social media platforms. Our results showed that collective opinion and risk-taking played a partial mediator role in the relationship between social recognition and political content sharing on social media.

Participants interested in social recognition were more likely to have collective opinions. One needs to be approved by others to be recognized by them. Others' opinions influence one's behavior (Lim \& Ting, 2014). In fact, one out of every five social media users is influenced by the political content they see in their feed (Duggan \& Smith, 2016). Moreover, most people tend to like highly-acclaimed social media feeds more (Sakamato, 2009). Therefore, we can argue that people who care about social recognition are more likely to have collective opinions. People who share their political opinions on social media platforms to be socially recognized target like-minded people. However, sharing political content on social media poses various risks.

Sharing political content on social media may get you in trouble! Social media users who share their political opinions face threats or legal sanctions (Grimmelmann, 2009), get their privacy invaded (Jernigan \& Mistree, 2009), or become targets of cyberbullying (Palfrey, 2008). Therefore, people sharing political content on social media not only consider collective opinions but also take risks. People engaging in risky behavior tend to think that no harm will come to them (Lapsley, Milstead, Quintana, Flannery \& Buss, 1986). Therefore, we can state that people yearning for social recognition take risks and share their political opinions on social media platforms. 
Participants with high impulsiveness were more likely to share political content on social media, which is not surprising because impulsive people act without thinking about its consequences (Park, Keil, Bock \& Kim, 2016). The results also showed that participants with high impulsiveness took more risks and shared political content on social media platforms. Impulsiveness is characterized by (1) acting without thinking and (2) engaging in extreme and high-risk activities (Romer, 2010). Therefore, we can argue that impulsive people are more likely to share political content on social media because they overlook or underestimate possible risks.

In conclusion, we can state that people who share their political opinions on social media platforms to be socially recognized are interested in having collective opinions and taking risks. We can also assert that impulsive people tend to share political content on social media because they overlook or underestimate the consequences of their actions and are more likely to take risks. These results beg for further interpretation. Most importantly, participants perceived political content sharing as risky behavior, as shown by the examples in the Introduction section. Another interpretation is that social media posts are affected by others' presence, regardless of whether they agree with those posts. Being visible by others affects what kind of posts one shares. Behaviors are more complex than what the TPB suggests (Ajzen, 1991). Interestingly, people who regard sharing political content on social media as risky still do so because they may have positive and negative attitudes towards certain situations, and behavior depends on which attitude is more dominant. Therefore, we should look into attitudes to explain behaviors. We can conclude that behavior has a complex structure depending on a variety of factors, some of which this study shed light on.

\section{Limitations and Future Research}

This study had two strengths. First, it had a large sample size, and second, it presented numerous results, which accounted for $52 \%$ of the factors affecting political content sharing on social media platforms. According to Yakar (2020), that rate is high in the field of social science research. The study had two limitations. First, participants were recruited from only one university in Turkey, and therefore, the results cannot be generalized. We recommend that researchers recruit more students from different universities with diverse backgrounds and replicate this study to detect differences in social media use patterns. Second, the data were based on self-report rather than observation or experimentation. Therefore, future studies should adopt experimental designs, perform interviews, or monitor students' social media use patterns. 


\section{References | Kaynakça}

Ajzen, I. (1991). The theory of planned behavior. Organizational Behavior and Human Decision Process, 50, $179-211$.

Akça, B. (2017). Determination of The Relationship Between The Science Anxiety and Science Related Intellectual Risk-Taking Behaviors of Middle School Students (Unpublished master thesis). Adnan Menderes Universtiy, Institute of Science, Aydın/Turkey.

Antczak, S. (2016). When your friends don't share your politics. https://www.forbes.com/sites/nextavenue/2016/02/16/when-your-friendsdont-share-your-politics/\#6bc583ba5c32, Accessed 08/03/2019.

Bentler, P. M., \& Bonett, D. G. (1980). Significance tests and goodness of fit in the analysis of covariance structures. Psychological Bulletin, 88, 588-606.

Bock, G.W. \& Kim, Y.G. (2002). Breaking the myths of rewards: an exploratory study of attitudes about knowledge sharing. Information Resources Management Journal, 14-21.

Bollen, K. A. (1989). A new incremental fit index for general structural equation models. Sociological Methods \& Research, 17(3), 303-316. doi: 10.1177/0049124189017003004

Browne, M.W., \& Cudeck, R. (1993). Alternative Ways of Assessing Model Fit. In K. A. Bollen \& J. S. Long (Eds.), Testing Structural Equation Models (pp. 136-162). Newbury Park, CA: Sage.

Bhutia, J. (2015). Man faces 32-year jail term for Facebook 'like' of doctored photo of king. http://www.ibtimes.co.uk/ thailand-man-faces-32-year-jail-term-facebook-like-doctored-photo-king-1532851. Accessed 01/02/2021

Byrnes, J. P., Miller D. C., \& Schafer, W. D. (1999). Gender differences in risk taking: A Meta-Analysis. Psychological Bulletin, 125, 367-383.

Ceyhan, A. A., \& Yelpaze, İ. (2017). Young Adults' Facebook Use Behaviors and Perceived Communication Skills. The Journal of Buca Faculty of Education, 44, 152-168.

Chaffey, D. (2019). Global social media research summary 2019. https://www.smartinsights.com/social-media-marketing/social-media-strategy/new-global-social-media-research/ Accessed 08/03/2019.

Digital (2019): Global digital overview. https://datareportal.com/reports/digital-2019-global-digital-overview. Accessed 08/02/2019.

Duggan, M. \& Smith, A. (2016). The political environment on social media. Pew Research Centre.

Dwivedi, Y. K., Rana, N. P., Jeyaraj, A., Clement,M., \& Williams,M. D. (2017). Re-examining the unified theory of acceptance and use of technology (UTAUT): Towards a revised theoretical model. Information Systems Frontiers, 1-16. https://doi.org/10.1007/s10796-017-9774-y.

Fogel, J., \& Nehmad, E. (2009). Internet social network communities: Risk taking, trust, and privacy concerns. Computers in Human Behavior, 25(1), 153-160.

Gençtanırım, D. (2014). University form of Risk Behaviors Scale: Validity and reliability studies. Journal of Measurement and Evaluation in Education and Psychology, 5(1), 24-34.

Grimmelmann, J. T. (2009). Facebook and the social dynamics of privacy. Iowa Law Review, 95(4), 1-52.

Grunbaum, J. A., Kann, L., Kinchen, S., Ross, J., Hawkins, J., Lowry, R., ... \& Collins, J. (2004). Youth risk behavior surveillance--United States, 2003. Morbidity and Mortality Weekly Report. Surveillance Summaries (Washington, DC: 2002), 53(2), 1-96.

Gullone, E., \& Moore, S. (1996). Predicting adolescent risk behavior using a personalized cost- benefit analysis. Journal of Youth and Adolescence, 25(3).

Hars, A., \& Ou, S. (2002). Working for free? Motivations for participating in open-source projects. International Journal of Electronic Commerce, 6(3), 25-39. 
Hollander, E., \& Evers, M. (2001). New developments in impulsivity. The Lancet, 358(9286), 949-950.

Hooper, D., Coughlan, J., \& Mullen, M. (2008). Structural equation modelling: Guidelines for determining model fit. Electronic Journal of Business Research Methods, 6(1), 53-60.

Hossain, M. A., Dwivedi, Y. K., Chan, C., Standing, C., \& Olanrewaju, A. S. (2018). Sharing political content in online social media: A planned and unplanned behaviour approach. Information Systems Frontiers, 20(3), 485-501. https://doi.org/10.1007/s10796-017-9820-9

Jernigan, C., \& Mistree, B. (2009). Gaydar: Facebook friendships expose sexual orientation. First Monday, 14(10).

Kacen, J. J., Hess, J. D., \&Walker, D. (2012). Spontaneous selection: The influence of product and merchandising factors on consumer impulse purchases. Journal of Retailing and Consumer Services, 19, 578-588.

Kapoor, K. K., \& Dwivedi, Y. K. (2015). Metamorphosis of Indian electoral campaigns: Modi's social media experiment. International Journal of Indian Culture and Business Management, 11(4), 496-516. https:// doi.org/10.1504/ijicbm.2015.072430.

Kuran Esen, B. (2002). Investigation of risk taking behaviour, smoking and achievement of students of various levels of peer pressure (Unpublished doctoral thesis). Gazi University, Ankara.

Kline, R. B. (2015). Principles and practice of structural equation modeling. New York: Guilford publications.

Lahno, A. M., \& Serra-Garcia, M. (2015). Peer effects in risk taking: Envy or conformity?. Journal of Risk and Uncertainty, 50(1), 73-95.

Lapsley, D. K., Milstead, M., Quintana, S. M., Flannery, D., \& Buss, R. R. (1986). Adolescent egocentrism and formal operations: Tests of a theoretical assumption. Developmental Psychology, 22(6), 800.

Li, H., \& Sakamoto, Y. (2014). Social impacts in social media: An examination of perceived truthfulness and sharing of information. Computers in Human Behavior, 41, 278-287.

Ma, W. W. K., \& Chan, A. (2014). Knowledge sharing and social media: Altruism, perceived online attachment motivation, and perceived online relationship commitment. Computers in Human Behavior, 39, 51-58.

Nasser-Abu Alhija, F., \& Wisenbaker, J. (2006). A Monte Carlo study investigating the impact of item parceling strategies on parameter estimates and their standard errors in CFA. Structural Equation Modeling, 13(2), 204-228.

Olsen, S. O., Tudoran, A. A., Honkanen, P., \& Verplanken, B. (2016). Differences and similarities between impulse buying and variety seeking: A personality-based perspective. Psychology \& Marketing, 33(1), 36-47. https://doi.org/10.1002/mar.20853.

Orr, A. (2012). Facebook post could send Perth student to Bangladesh jail. http://www.watoday.com.au/wa-news/ facebook-post-could-sendperth-student-to-bangladesh-jail-20120115-1q119.html. Accessed 02/07 2019.

Osatuyi, B. (2013). Information sharing on social media sites. Computers in Human Behavior, 29(6), 2622-2631.

Osborne, J. W. (2013). Best practices in data cleaning. California: Sage Publication, Inc.

Palfrey, J. (2008). Enhancing child safety and online technologies: In Internet safety task force. http://cyber.law. harvard.edu/pubrelease/isttf/ Accessed at 10.01.09

Park, J. H., Gu, B., Leung, A. C. M., \& Konana, P. (2014). An investigation of information sharing and seeking behaviors in online investment communities. Computers in Human Behavior, 31, 1-12. https://doi. org/10.1016/j.chb.2013.10.002.

Park, S. C., Keil, M., Bock, G.W., \& Kim, J. U. (2016).Winner's regret in online C2C auctions: An automatic thinking perspective. Information Systems Journal, 26(6), 613-640. https://doi.org/10.1111/isj.12075.

Peterson, F. L., Walker, L., Whatt, T. J., Rheinboldt, K., White, C., \& Hogkinson, M. (2003). Evidence-based sexuality education. American Public Health Association Annual Conference San Francisco, California, 


\section{insan \& toplum}

November 18 .

Romer, D. (2010). Adolescent risk taking, impulsivity, and brain development: Implications for prevention. Developmental Psychobiology: The Journal of the International Society for Developmental Psychobiology, 52(3), 263-276.

Sakamoto, Y., Ma, J., \& Nickerson, J. V. (2009). 2377 people like this article: The influence of others' decisions on yours. In: Proceedings of the 31st Annual Conference of the Cognitive Science Society.

Schreiber, J. B., Nora, A., Stage, F. K., Barlow, E. A., \& King, J. (2006). Reporting structural equation modeling and confirmatory factor analysis results: A review. The Journal of Educational Research, 99(6), 323-338. doi: 10.3200/JOER.99.6.323-338.

Shiau, W.L., \& Chau, P. Y. K. (2015). Does altruism matter on online group buying? Perspectives from egotistic and altruistic motivation. Information Technology \& People, 28(3), 677-698. https://doi.org/10.1108/ ITP-08-2014-0174.

Stutzman, F. (2006). An evaluation of identity-sharing behavior in social network communities. iDMAa Journal, 3(1), 1-7

Stutzman, F., Capra, R., \& Thompson, J. (2011). Factors mediating disclosure in social network sites. Computers in Human Behavior, 27(1), 590-598.

Tabachnick, B. G., \& Fidell, L. S. (2001). Using multivariate statistics (4th ed.). Needham Heights, MA: Allyn \& Bacon.

van Duijvenvoorde, A. C., Blankenstein, N. E., Crone, E. A., \& Figner, B. (2017). Towards a better understanding of adolescent risk taking: Contextual moderators and model-based analysis. Individual differences in judgment and decision making from a developmental perspective, 8-27.

Yakar, L. (2020). Korelasyon. In F. Orçan (Ed.)., Sosyal Bilimlerde İstatistik, Excel ve SPSS Uygulamaları (93-138). Ankara: Anı Publication.

Willoughby, T., Good, M., Adachi, P. J. C., Hamza, C., \& Tavernier, R. (2013). Examining the link between adolescent brain development and risk taking from a social-developmental perspective. Brain and Cognition, 83, 315-324. doi:10.1016/j.bandc.2013.09.008. 